\title{
Jurnal
}

Manajemen Kesehatan Indonesia

\section{Analisis Implementasi Keselamatan dan Kesehatan Kerja pada Masa Pandemi COVID-19 Bagi Karyawan di Rumah Sakit X Kabupaten Karanganyar}

\author{
Siti Hamurwani*, Hanifa Maher Denny*, Daru Lestantyo* \\ *Fakultas Kesehatan Masyarakat, Universitas Diponegoro \\ Email: sitihamurwani82@gmail.com
}

\section{ABSTRACT}

The world is currently facing the COVID-19 pandemic; therefore, the implementation of occupational safety and health (OSH) program in the hospital is very important to protect health care workers from the risk of being exposed to the COVID-19 disease. This study aimed to elucidate the implementation of the OSH program in preventing the transmission of COVID-19 to employees at Karanganyar District General Hospital. This research used qualitative methods. The researchers observed the study site, conducted in-depth interviews, and reviewed the documents. Seven informants were selected as informants, and then the information was triangulated to two subjects. The results showed that OSH's implementation in the study site complied with the Ministry of Health Guidelines for Hospital Services During New Adaptation, 2 November 2020. In terms of cultivating safety and health behavior at work, the hospital provided information and educational sessions. The morning briefing, a periodical reminder to implement safety and health, standing banners and posters, provision of guidelines and standards operating procedures were the pieces of evidence to prevent the transmission of COVID-19 in the hospital study site. The hospital emergency response team was part of the hospital's COVID-19 task force team. The facilities and enforcement of health protocols to prevent
COVID-19 transmission in the study site were well established.

Keywords: Occupational Health and Safety, Covid-19, Hospital

\section{PENDAHULUAN}

Kebijakan Pemerintah yang tertuang dalam Permenkes RI No 66 Tahun 2016 menyebutkan bahwa semua rumah sakit wajib menyelenggarakan $\mathrm{K}_{3} \mathrm{RS}^{12}$, karena rumah sakit menjadi salah satu tempat kerja yang paling berbahaya. Rumah sakit dalam memberikan pelayanan kesehatan memiliki banyak sekali risiko bahaya baik bagi pasien, pengunjung dan juga tenaga kesehatan di rumah sakit. Risiko bahaya di rumah sakit hampir dua kali lipat dari industri swasta. ${ }^{3}$ Manajemen rumah sakit harus berupaya secara maksimal dalam meminimalkan dan melakukan pengendalian bahaya dan risiko; pencegahan kecelakaan dan cidera; juga menjaga kondisi aman. ${ }^{14}$

Dunia saat ini sedang menghadapi wabah pandemi COVID-19 yang telah menyebar ke seluruh negara. ${ }^{5}$ COVID-19 adalah penyakit menular yang penyebabnya dari sindrom pemapasan akut coronavirus 2 (severe acute respiratory syndrome coronavirus 2 atau SARS-CoV-2). ${ }^{6}$ Petugas pelayanan kesehatan mendapatkan risiko kesehatan kerja yang ditimbulkan dari penyakit COVID-19. Ribuan petugas pelayanan kesehatan telah terinfeksi 
COVID-19, terutama petugas pelayanan kesehatan di China. $^{7}$

Rumah Sakit X sebagai salah satu rumah sakit rujukan Covid-19 di Kabupaten Karanganyar memiliki potensi bahaya yang sangat tinggi terhadap penularan Covid-19. Berdasarkan data yang didapat dari Rumah Sakit X menyebutkan bahwa karyawan rumah sakit yang terinfeksi COVID-19 sejak dimulainya pandemi sebanyak 96 orang, terdiri dari tenaga kesehatan sebanyak 70 orang, tenaga penunjang sebanyak 20 orang dan manajemen sebanyak 8 orang. Banyaknya petugas pelayanan kesehatan yang terinfeksi COVID-19 disebabkan oleh kurangnya pemahaman dan kesadaran tentang perlindungan pribadi, lamanya waktu petugas pelayanan kesehatan terpajan dengan pasien yang terinfeksi COVID-19, kurangnya ketersediaan Alat Pelindung Diri (APD) yang memadai dan kurangnya pengetahuan tentang penyakit menular yang penularannya melalui pemafasan. ${ }^{8}$ karena itu peneliti mengajukan penelitian dengan judul "Analisis implementasi K3RS pada masa pandemi COVID-19 bagi karyawan di RS X Kabupaten Karanganyar".

\section{METODE PENELITIAN}

Penelitian ini menggunakan metode pengumpulan data berdasarkan hasil observasi, wawancara mendalam (indepth interview) dan studi pustaka. Telah lolos kaji etik oleh Komisi Etik Penelitian Kesehatan FKM Undip dengan nomor sertifikat 257/EA/KEPK-FKM/2020. Tujuan dari penelitian ini adalah menganalisis penerapan program K3RS dalam rangka pencegahan penularan COVID-19 pada karyawan di Rumah Sakit. Subyek yang digunakan dalam penelitian ini dipilih dengan menggunakan teknik purposive sampling, yaitu sampel yang dipilih secara sengaja yang ditentukan berdasarkan keterlibatan yang bersangkutan terhadap situasi/kondisi yang akan diteliti. Didapatkan sebanyak 9 orang terdiri dari tim K3 4 orang, petugas IPCN 2 orang dan tim gugus tugas penanganan Covid193 orang. Metode dalam pengolahan data dengan teknik transkripsi data, pengkodean, mendeskripsikan, menghubungkan tema dan menginterpretasikan.

\section{HASIL DAN PEMBAHASAN}

Penerapan program K3RS di Rumah Sakit antara lain melalui pengembangan kebijakan K3RS, pembudayaan perilaku K3RS, pengembangan pedoman dan standar operational procedure (SOP) dan manajemen tanggap darurat. Dalam hal pengembangan kebijakan K3RS sudah dibentuk tim keselamatan dan kesehatan kerja rumah sakit yang didalamnya juga menyebutkan tugas ketua, wakil ketua, sekretaris, koordinator bidang dan anggota-anggotanya. Pembentukan tim K3RS ini disahkan dalam bentuk Surat Keputusan Direktur Nomor 445/151.25 Tahun 2020 tentang Pembentukan Tim Keselamatan dan Kesehatan Kerja (K3) Rumah Sakit.

Keanggotaan tim tersebut dari berbagai macam profesi yang ada di rumah sakit yaitu perawat, sanitarian, umum rumah tangga, IPSRS, Penunjang, bagian keamanan dan Dokter yang kesehariannya memiliki tupoksi utama.

Untuk point ini bisa disimpulkan bahwa Rumah Sakit sudah sesuai Permenkes RI No. 66 Tahun 2016 yaitu menyelenggarakan K3RS dan telah ditetapkan dengan Surat Keputusan Direktur meskipun masih sebatas tim sehingga program kegiatan belum dapat terlaksana secara maksimal, seperti kegiatan sosialisasi tidak dapat berjalan sesuai jadwal yang sudah

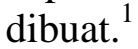

Pembudayan perilaku K3 bertujuan supaya petugas/pekerja berperilaku sehat dan selamat dalam bekerja sehingga tidak menyebabkan kecelakaan kerja. ${ }^{910}$ Rumah sakit telah melaksanakan kegiatan yaitu berupa sosialisasi tentang penggunaan APAR dan praktek hand hygiene pada saat apel pagi, penyampaian pesan kesehatan melalui media seperti standing banner, poster, media pengeras suara dan sosialisasi keliling bangsal-bangsal. Hal ini sejalan dengan penelitian Maleke, dkk (2019) dimana dalam pembudayaan perilaku 
K3RS sudah dilakukan dengan kegiatan sosialisasi dan pemasangan poster-poster. ${ }^{11}$

"Pembudayaan perilaku yang dilakukan dengan sosialisasi mba,,,,emmm,,,sama penyampaian pesan kesehatan lewat pengeras suara, trus... ada standing banner juga, poster juga ada" IU1

Namun untuk kegiatan sosialisasi keliling ke bangsal belum bisa berjalan rutin karena keterbatasan SDM. SDM yang ada saat ini dalam tim K3 hanya merupakan tugas tambahan, masing-masing mempunyai tugas pokok/pekerjaan utama. Dalam penelitian Purnamasari, dkk (2013) disebutkan bahwa di dalam sebuah manajemen, sumber daya yang penting adalah sumber daya manusia. ${ }^{12}$

Penerapan SOP menjadi salah satu faktor yang sangat berpengaruh dengan kejadian kecelakaan kerja. Karena tujuan dari SOP adalah agar semua petugas mengetahui tugas dan peran dalam pekerjaannya, alur kerja dan kewenangannya, menjaga kinerja dan melindungi petugas supaya terhindar dari kesalahan. ${ }^{13}$ Berdasarkan telaah dokumen diketahui bahwa Rumah Sakit sudah sesuai karena telah membuat SOP dalam pelaksanaan pencegahan penularan COVID-19 di rumah sakit. SOP yang sudah dibuat yaitu desinfeksi ruang isolasi COVID-19, desinfeksi sederhana, desinfeksi ambulance, general cleaning, pengelolaan limbah padat khusus COVID-19 di TPS B3 dan di ruangan, SOP pelepasan APD petugas pemulasaraan jenazah, pemulasaraan jenazah COVID-19 dan pengangkutan jenazah COVID-19. Namun rumah sakit belum menyusun pedoman tertulis tentang pencegahan penularan COVID-19.

Manajemen tanggap darurat yang dilakukan kaitannya dengan peningkatan kasus jumlah pasien yaitu Rumah Sakit telah melakukan skrining pasien masuk dengan dilakukan pemeriksaan suhu di pintu masuk rumah sakit, hal ini sesuai dengan panduan teknis kementerian kesehatan tentang pelayanan RS pada masa adaptasi kebiasaan baru. ${ }^{14}$

"Awal masuk pasien entah itu di IGD
maupun di poliklinik tentunya itu akan
melalui beberapa skrining pasien
masuk,,,itu kalau di tempat kita kan
kelihatan di depan sudah ada petugas
skrining yang membawa thermogan itu
memulai skrining awal memulai dari
meminta penjelasan terkait dengan riwayat
dan sebagainya itu sudah ada
panduannya,,trus eee...semua pasien
maupun eee...penunggu pasien itu
semuanya melalui skrining yang ada
didepan" IU6

Rumah Sakit juga menyediakan ruang isolasi pasien COVID-19, melaksanakan pembatasan jam kunjung, pembatasan jumlah pasien dan penerapan physical distancing/menjaga jarak dengan memberi tanda silang pada kursi tunggu. Hal ini sudah sesuai dengan panduan teknis kementerian kesehatan tentang pelayanan RS pada masa adaptasi kebiasaan baru. ${ }^{14}$

"kursi tunggu dikasih tanda silang untuk pengaturan jaga jarak, pembatasan jam kunjung, pembatasan jumlah pasien, penyediaan ruang isolasi" IU2

Ruang isolasi pasien COVID-19 harus dilakukan pengaturan tata udara, ruangan harus bertekanan negative, terdapat ruang anteroom dan satu kamar untuk satu pasien. Rumah Sakit sudah sesuai dengan menyediakan 2 bangsal untuk ruang isolasi yaitu Sakura dan Anggrek dimana sudah memenuhi standar minimal ruang isolasi, yaitu meskipun dalam pengaturan tata udara belum menggunakan alat mekanik tetapi dengan menggunakan hepa filter portabel, penggunaan exhaust, penyediaan ruang anteroom dan satu kamar hanya diisi satu pasien. Menurut informan triangulasi penggunaan hepa filter portabel dinilai sudah aman karena juga didukung dengan penerapan protokol kesehatan dengan melaksanakan five moments. Dalam WHO disebutkan tentang pentingnya melaksanakan five moments untuk melindungi diri sendiri pada saat bekerja. ${ }^{15}$ 
"Kalau setau saya persyaratannya ya ruangan harus ada pengaturan tata udara, tekanan harus negatif, tersedia ruang anteroom, satu kamar diisi satu pasien. Disini paling tidak standar minimal sudah bisa memenuhilah,,, di ruang isolasi menggunakan hepafilter portabel, ada ruang anteroom dan satu kamar diisi satu pasien" IU2

"Ruang isolasi sudah disediakan dengan mengacu standart, yaitu ada anteroom, dilengkapi hepafilter, dan alat kesehatan yang sesuai kebutuhan " $\quad$ IT1

Dalam pedoman umum menghadapi COVID-19 disebutkan bahwa institusi kesehatan harus menunjuk dan membentuk kelompok ahli dalam pencegahan dan pengendalian atau tim gugus tugas penanganan COVID-19. ${ }^{1617}$ Manajemen tanggap darurat yang dilakukan rumah sakit dalam melindungi karyawan sudah sesuai yaitu sudah dibentuk tim gugus tugas penanganan COVID-19 dan juga telah dibuat beberapa kebijakan untuk pelaksanaan pencegahan penularan COVID-19 di rumah sakit. Kebijakan yang telah dibuat yaitu tentang skrining pasien masuk dengan pemeriksaan suhu di pintu masuk, kebijakan penggunaan APD, kebijakan tentang pemisahan pintu masuk karyawan dan pintu masuk pasien, kebijakan tentang peniadaan absen dengan finger print dan kebijakan tentang zonasi ruangan.

"Kebijakan sudah ada, sudah dibuat SK
tentang pencegahan penularan Covid-19
dan sudah dibentuk tim gugus tugas
penanganan Covid-19" IU1
"Ya, kebijakan sudah ada, untuk
penanganan covid secara khusus sudah
dibentuk tim gugus tugas penanganan
covid" IU2
Keselamatan dan kesehatan petugas pelayanan kesehatan dan juga staf yang lain di tempat pelayanan kesehatan adalah hal yang sangat penting. Karena tidak hanya untuk memberikan perlindungan kepada mereka tetapi juga untuk membantu dalam mencegah penyebaran virus dan meningkatkan pelayanan secara keseluruhan. ${ }^{18}$ Kegiatan dalam pencegahan penularan COVID-19 di rumah sakit sudah sesuai panduan teknis kementerian kesehatan tentang pelayanan RS pada masa adaptasi kebiasaan baru yaitu pembuatan mapping area berisiko, pembuatan pembatas/barrier, melakukan pemeriksaan suhu di pintu masuk rumah sakit, pemberian vitamin bagi petugas/karyawan di rumah sakit dan penyediaan APD sesuai kebutuhan.

"Kalau eemmm...untuk kegiatan yang sudah dilakukan itu seperti pembuatan pembatas/barrier, pemeriksaan suhu di pintu masuk, penyediaan APD, pemberian vitamin bagi petugas nakes trus emmm....peniadaan absen dengan finger print dll" IU1

"pemasangan barrier pada tempat-tempat yang kontak langsung dengan pasien seperti di pendaftaran kemudian di poliklinik dan tempat lainnya" IU7

Rumah sakit juga menyediakan ruang isolasi khusus untuk karyawan yang memerlukan isolasi mandiri, melaksanakan edukasi, pendidikan dan pelatihan terkait COVID-19, tidak melaksanakan kegiatan yang melibatkan massa dalam jumlah besar, membatasi peserta rapat dan membatasi peserta didik. Hal ini sesuai dengan Pedoman Standar Perlindungan Dokter di Era COVID bahwa salah satu pengendalian administratif yaitu dengan pembatasan peserta rapat. ${ }^{19}$ Rumah sakit juga membuat kebijakan tentang pintu masuk karyawan dan pasien yang semula menjadi satu kemudian sekarang dipisah.

"ruang isolasi WK 2 untuk nakes, nakes 
dan keluarga karyawan rumah sakit"
IU7
"pelaksanaan edukasi, pendidikan dan
pelatihan terkait Covid-19..... tidak
mengadakan kegiatan dengan jumlah massa
yang banyak, pembatasan peserta rapat,
pembatasan peserta didik" IU4

Dalam melaksanakan kegiatan pencegahan penularan COVID-19, berdasarkan wawancara mendalam diketahui bahwa kendala yang dihadapi rumah sakit yaitu pihak keluarga pasien seringkali tidak kooperatif, tidak disiplin dalam memakai masker sehingga petugas harus berulangkali memberikan edukasi kepada keluarga pasien untuk memakai masker. Selain itu pasien juga kadang tidak jujur dengan keluhan yang dirasakan sehingga petugas kecolongan dan pasien lolos skrining. Setelah di rawat beberapa hari barulah muncul tandatanda suspek dan setelah di dilakukan swab ternyata pasien positif COVID-19. Rosita (2020) dalam penelitiannya mengatakan bahwa ketidakjujuran pasien dalam menyampaikan informasi kesehatan dapat mengakibatkan misdiagnosis sehingga tindakan yang diberikan tidak maksimal atau bahkan dapat mengakibatkan Dokter terpapar COVID-19 apabila ternyata pasien tersebut positif COVID$19^{20}$

"trus kemudian juga kadang beberapa
pasien tidak jujur dengan keluhan yang
dirasakan. Jadi kayak kita kecolongan gitu"
IU2
"ditambah faktor dari luar yaitu dari pasien
dan keluarga pasien. Sulitnya edukasi ke
pasien dan keluarga pasien menjadi
masalah utama pula" $\mathbf{I U 3}$

Dari sisi internal juga muncul kendala yaitu bahwa petugas kesehatan sudah mulai merasa kelelahan dalam menghadapi pandemi COVID-19 karena trend jumlah kasus positif Covid semakin hari semakin naik. Hal ini seperti penelitian Mulu, dkk (2020) bahwa pandemi COVID-19 memiliki dampak bagi petugas pelayanan kesehatan yaitu penurunan stabilitas mental dan meningkatkan kemungkinan stress dan kecemasan. ${ }^{21}$ Dalam penelitian Matthew dkk (2020) juga menyebutkan bahwa petugas kesehatan menghadapi tekanan mental dan juga kelelahan fisik dan mental dalam merawat pasien COVID-19. ${ }^{22}$

"Kendalanya eee...apa
mba...kendalanya memang yang paling
berat itu di psikis mba, di psikis dari
temen-temen nakes itu memang sampai
saat ini yowes radak kelelahan. Diharapkan
kemarin dari prediksi itu puncaknya kan di
April, eee....kita kan apa ya...mindset
pikiran kita wah bulan Mei sudah trendnya
sudah turun tapi ternyata apa yang ada
bulan April tuh pasiennya sudah banyak
bulan Mei harapannya sudah eee...apa
ya...ada penurunan ternyata
eee...apa...grafiknya malah munggah, trus
semakin kesini semakin kesini harapannya
itu ya sudah bisa dikendalikan dengan
aman tapi itu secara psikis ketika kita
melihat angkanya yang di kabupaten
Karanganyar ternyata trendnya kok malah
tambah meledak meledak terus kita yoo
wah kapan lerene gitu" IU6

Berdasarkan wawancara mendalam diketahui bahwa yang bertanggung jawab dalam pelaksanaan pencegahan penularan COVID-19 di Rumah Sakit adalah semua elemen mulai dari tingkat atas sampai dengan tingkat bawah. Hal ini sejalan dengan penelitian Singkun (2020) bahwa kegiatan pencegahan dan pengendalian COVID-19 semua orang harus ikut bertanggung jawab. ${ }^{23}$ Tetapi secara khusus yang bertanggung jawab adalah tim K3, Komite PPI dan tim gugus tugas penanganan COVID-19.

Rumah Sakit telah menyiapkan alokasi dana dan untuk ketersediaannya mencukupi. Dana tersebut berasal dari dana APBD dan dana BLUD Rumah Sakit. Penyediaan dana tersebut tidak dalam satu rekening anggaran 
tetapi terdapat pada beberapa rekening anggaran meliputi rekening bahan kebersihan COVID, alat kebersihan COVID, belanja pakaian dan APD COVID, jasa kebersihan ruang isolasi dan belanja linen (masker, baju dll). Total anggaran yang disediakan untuk pencegahan penularan COVID-19 di rumah sakit kurang lebih 4,3 miliar, dan anggaran terbesar terdapat pada rekening belanja pakaian dan APD covid yaitu sebesar 4 miliar.

Rumah Sakit dalam menyediakan sarana prasarana sudah baik yaitu ruang isolasi, APD, sarana cuci tangan, handrub, sekat pembatas/barrier, desinfektan dan juga suplemen untuk karyawan dan ketersediaannya mencukupi. Hal ini sejalan dengan penelitian Afaf Khansa (2020) menyebutkan bahwa dalam menghadapi pandemi COVID-19 telah menyediakan fasilitas seperti tempat cuci tangan, alat pelindung diri (hazmat suit, gloves, googles, face shield, medical mask/N95), handsanitizer, TGC (tim gerak cepat).

\begin{tabular}{|l|}
\hline "Kita memenuhi kebutuhan sarana \\
prasarana termasuk sarana prasarana ruang \\
isolasi, alat kesehatan khusus pasien covid, \\
APD, suplemen NAKES, sekat pada ruang \\
administratif dan lainnya" IU4
\end{tabular}

Risiko penularan infeksi petugas kesehatan dapat diminimalisir denga penggunaan alat pelindung diri. ${ }^{22}$ Rumah Sakit sudah sesuai dengan panduan teknis kementerian kesehatan tentang pelayanan RS pada masa adaptasi kebiasaan baru yaitu membuat kebijakan penggunaan dan menyediakan APD. APD yang disediakan yaitu kaca mata google, face shield, masker kain, masker bedah, masker N95, sarung tangan, baju gawn, hazmat, cover all, sepatu boot, cover sepatu, apron, penutup kepala dan nurse cap.

"Alat pelindung dirinya ya cover all, google, face shield, masker N95, masker bedah, apron, gown, sarung tangan panjang, sarung tangan, sepatu boot, cover sepatu, masker kain" IU4
Ketersediaan APD di rumah sakit jumlahnya sampai saat ini mencukupi, manajemen memberikan tanggung jawab Komite PPI untuk mengontrol, mengawasi dan menjaga ketersediaan stok APD. Dalam penyediaan APD, berdasarkan wawancara mendalam diketahui bahwa kendala terjadi pada awal-awal pandemi, ketersediaan APD menipis karena kelangkaan APD dan harga APD relatif mahal. Tetapi untuk saat ini sudah lancar dalam penyediaan APD. Seperti yang diungkapkan dalam penelitian Mulu, dkk (2020) menyebutkan bahwa di beberapa wilayah APD menjadi sesuatu yang langka dan mahal pada saat perawatan pasien COVID-19. ${ }^{21}$

"Aman insyaallah, selama ini dari pihak manajemen memberikan tugas komite PPI untuk mengontrol, mengawasi, dan menjaga stok agar kebutuhan APD selalu aman...." IU3

Untuk mengantisipasi kelangkaan APD pada awal pandemi, rumah sakit diwakili dari bagian Kesling, tim K3 dan Komite PPI berinisiatif membuat sendiri masker kain dari bahan spoundbond, face shield dan masker. Selain itu rumah sakit juga mendapatkan donasi masker dari beberapa organisasi masyarakat. Dalam penelitian Simatupang (2017) menyebutkan juga bahwa selain dari pengadaan sendiri, rumah sakit juga mendapatkan APD dari bantuan pihak luar salah satunya dari kementrian kesehatan. ${ }^{24}$

Rumah sakit mengalami kedala dalam penegakkan disiplin penggunaan APD yang kadang berlebihan dalam artian menggunakan APD tidak sesuai dengan risiko paparannya dan juga dari petugas beberapa melepas APD kemudian meletakkan sembarangan tidak dimasukkan dalam bin. Hal ini tidak sejalan dengan penelitian Rowan, dkk (2020) bahwa solusi dalam mengatasi ketersediaan APD adalah dengan menggunakan APD secara hemat sesuai dengan risiko. ${ }^{25}$ 
Protokol kesehatan yang dilaksanakan di Rumah Sakit adalah 3M (memakai masker, mencuci tangan dan menjaga jarak), memakai APD sesuai potensi bahaya di tempat kerja dan melaksanakan hand hygiene di tempat kerja. Ketersediaan sarana prasarana untuk pelaksanaan hand hygiene mencukupi. Fasiltas handrub tersedia di semua bed pasien.

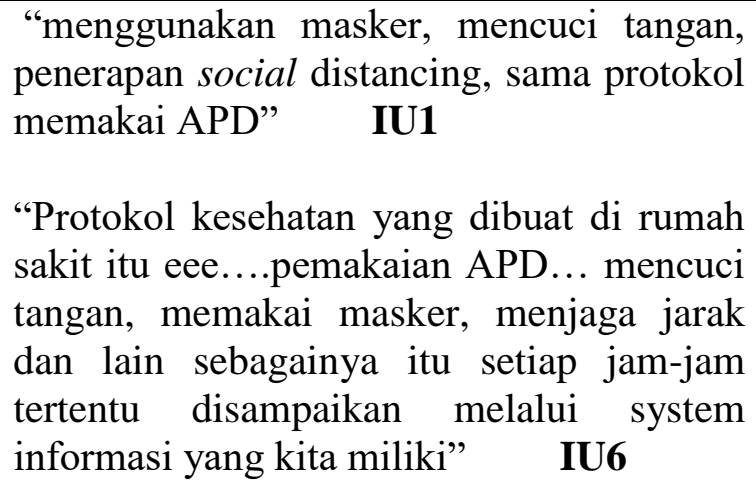
penerapan social distancing, sama protokol memakai APD" IU1

"Protokol kesehatan yang dibuat di rumah sakit itu eee....pemakaian APD... mencuci tangan, memakai masker, menjaga jarak dan lain sebagainya itu setiap jam-jam tertentu disampaikan melalui system informasi yang kita miliki” IU6

\section{KESIMPULAN}

Penerapan K3RS dalam hal pengembangan kebijakan K3RS, pembudayaan perilaku K3RS, pengembangan pedoman dan SOP, manajemen tanggap darurat dalam rangka pencegahan penularan COVID-19 di Rumah Sakit sudah dilaksanakan dengan baik, meskipun ada beberapa kendala dalam pelaksanaannya seperti keterbatasan sumber daya manusia, belum disusunnya pedoman tertulis tentang pencegahan penularan COVID19, pihak keluarga pasien seringkali tidak kooperatif dan tidak disiplin dalam memakai masker, belum tersedianya anggaran penyediaan sistem tata udara secara mekanik di ruang isolasi, dan pemborosan APD karena penggunaan yang berlebihan dari petugas. Maka dari itu penulis memberikan saran agar rumah sakit menyediakan petugas purna waktu yang bertanggung jawab terhadap pelaksanaan program K3 di rumah sakit, agar disusun pedoman tertulis dalam pencegahan penularan COVID-19 di rumah sakit, agar rumah sakit melaksanakan edukasi, pelatihan dan monitoring kepatuhan penggunaan APD dan rumah sakit menyediakan gizi bagi seluruh pegawai.

\section{UCAPAN TERIMA KASIH}

Kami mengucapkan terimakasih kepada Direktur beserta seluruh staf dan pegawai Rumah Sakit yang telah mendukung dalam penulisan ini.

\section{DAFTAR PUSTAKA}

1. Peraturan Menteri Kesehatan Republik Indonesia Nomor 66 Tahun 2016 Tentang Keselamatan Dan Kesehatan Kerja Rumah Sakit. DOI: 10.5151/cidi2017-060.

2. Fadhila N, Sudiro, Denny HM. Analisis Upaya Manajemen Rumah Sakit Dalam Penerapan Budaya Kesehatan dan Keselamatan Kerja ( K3 ) Pasca Akreditasi pada Sebuah RSUD di Kabupaten Semarang. J Manaj Kesehat Indones 2017; 5: 55-61.

3. Kreimer S. Caring for caregivers. Hosp Heal Networks 2013; 87: 18-20.

4. Komisi Akreditasi Rumah Sakit. Instrumen Survey Standar Nasional Akreditasi Rumah Sakit Edisi 1.

5. Hidayat RH. Langkah-Langkah Strategis Untuk Mencegah Pandemi Covid-19 Di Lembaga Pemassyarakatan Indonesia. $J$ Pendidik Kesehat 2020; 9: 43-55.

6. Setiawan AR. Lembar Kegiatan Literasi Saintifik untuk Pembelajaran Jarak Jauh Topik Penyakit Coronavirus 2019 (COVID-19). J Ilmu Pendidik 2020; 2: 2837.

7. Gan WH, Lim JW, Koh D. Preventing Intra-hospital Infection and Transmission of Coronavirus Disease 2019 in Healthcare Workers. $J$ shaw. Epub ahead of print 2020. DOI: 10.1016/j.shaw.2020.03.001.

8. Wang J, Zhou M, Liu F. Exploring the reasons for healthcare workers infected with novel coronavirus disease 2019 (COVID-19) in China. J Hosp Infect. Epub ahead of print 2020. DOI: 10.1016/j.jhin.2020.03.002.

9. Yang C-C, Wang Y-S, Chang S-T, et al. A study on the leadership behavior, safety culture, and safety performance of the 
healthcare industry. World Acad Sci Eng Technol 2009; 53: 1148-1155.

10. Ardi SZ, Hariyono W. Analisa Penerapan Budaya Perilaku Keselamatan dan Kesehatan Kerja di Rumah Sakit. Kes Mas J Fak Kesehat Masy 2018; 12: 15-20.

11. Maleke AS, Kawatu PAT, Korompis GEC. Gambaran Pelaksanaan Program Kesehatan dan Keselamatan Kerja Di Rumah Sakit Umum GMIM Kalooran Amurang. $J$ Kesmas 2019; 8: 574-582.

12. Purnamasari I, Kapalawi I. Analisis Proses Manajemen Sumber Daya Manusia Di Rumah Sakit Stella Maris Makassar. J MKMI 2013; 120-124.

13. Prayitno H. Keselamatan Dan Kesehatan Kerja (K3) Pada Standard Operasional Prosedur (Sop ). Ponorogo, 2016.

14. Kementerian Kesehatan RI. Panduan Teknis Pelayanan Rumah Sakit Pada Masa Adaptasi Kebiasaan Baru. Jakarta, 2020.

15. WHO. The COVID-19 Risk Communication Package For Healthcare Facilities. Who 2020; 1-11.

16. Tim Kerja Kementerian Dalam Negeri. Pedoman Umum Menghadapi Pandemi Covid-19 Bagi Pemerintah Daerah: Pencegahan, Pengendalian, Diagnosis dan Manajemen. J Chem Inf Model 2013; 53: 1689-1699.

17. Keputusan Presiden Republik Indonesia Nomor 7 Tahun 2020 Tentang Gugus Tugas Percepatan Penanganan Corona Virus Disease 2019 (Covid-19).

18. World Health Organization (WHO). Infection prevention and control during health care when novel coronavirus $(\mathrm{nCoV})$ infection is suspected: interim guidance. (2020). Geneva: World Health Organization. WHO 2020; 1-5.

19. IDI P. Pedoman Standar Perlindungan Dokter di Era Covid-19. 2020.

20. Rosita D. Perlindungan Hukum Bagi Dokter Terhadap Pengobatan Pasien Covid-19 Di Rumah Sakit. Leg Standing J Ilmu Huk 2020; 4: 224.

21. Mulu GB, Kebede WM, Worku SA, et al. $<\mathrm{p}>$ Preparedness and Responses of
Healthcare Providers to Combat the Spread of COVID-19 Among North Shewa Zone Hospitals, Amhara, Ethiopia, 2020</p $>$. Infect Drug Resist 2020; Volume 13: 3171-3178.

22. Chersich MF, Gray G, Fairlie L, et al. COVID-19 in Africa: care and protection for frontline healthcare workers. 2020; $1-6$.

23. Singkun A. Factors associated with social responsibility among university students in Yala , Thailand during the COVID-19 pandemic. J Heal Res Emerarld Publ Ltd 2020; $1-11$.

24. Simatupang RB. Kesiapsiagaan RSPAD Gatot Soebroto dalam Penanggulangan Bencana Pandemi Influenza untuk Mengantisipasi Ancaman Bioterorisme. $J$ Prodi Manaj Bencana 2017; 3: 49-80.

25. Rowan NJ, Laffey JG. Challenges and solutions for addressing critical shortage of supply chain for personal and protective equipment ( PPE ) arising from Coronavirus disease ( COVID19) pandemic - Case study from the Republic of Ireland. Sci Total Environ 2020; 725: 138532. 